\title{
Chapter 9 \\ Bringing the Local Back In: How Schools Work Differently in Different Neighborhood Contexts
}

\author{
Julia Nast
}

Researchers seeking to explain the reproduction of educational inequality have not afforded local neighborhood settings a central role in the debate. Prominent theorists, such as those utilizing a Bourdieusian approach to educational inequality, analyze how homogenous social classes enter into a homogenous educational system in which the cultural capital of the dominant classes is advantaged (Bourdieu \& Passeron, 1970/1990). Although extremely helpful for understanding educational inequality, this perspective leaves little room to consider processes within specific schools (McDonough, 1997, p. 107) in different local settings and how this might add an additional layer to the reproduction of inequality.

If researchers take local conditions into account, they often do so through a theoretical framework of social composition. Following the Coleman report (Coleman et al., 1966), scholars have focused on whether different social (and other) compositions in classrooms and schools impact school performance. The central question becomes whether students generally perform better in schools with high socioecomic status or whether there is a separate effect beyond individual characteristics, meaning that segregation widens the achievement gap between high- and lowsocial-status groups (van Ewijk \& Sleegers, 2009, p. 135). Results vary from no effects to strong peer-group effects (see e.g., Evans, Oates, \& Schwab, 1992; Jencks \& Mayer, 1990). In any case, in this perspective local settings are reduced to producing specific social compositions in schools. Most researchers theorizing how these social compositions become meaningful focus on how children negatively impact each other through socialization or "contagion" of "bad" behavior (Thrupp, Lauder, \& Robinson, 2002, p. 484). Although the roles of teachers and parents have become more important in the debate, many scholars continue to focus on peergroup processes (Kahlenberg, 2003, p. 67; Opdenakker, van Damme, de Fraine, van Landeghem, \& Onghena, 2002, pp. 399-402, 423; Thrupp, 1999, p. 36).

J. Nast $(\bowtie)$

Phineo, Berlin, Germany

e-mail: julia.nast@phineo.org 
This focus on peer-group effects does more than risk blaming the victim-it also veils a crucial dimension of educational inequality, namely whether the quality of provision of public organizations such as schools may vary by neighborhood. As early as the 1960s, researchers demonstrated that educational organizations are not distributed equally over the city but that neighborhood choice impacts students' access to school types (see e.g., Freytag \& Jahnke, 2015, pp. 57, 111; Geipel, 1965; Meusburger, 1998, pp. 291-292; also Sykes \& Musterd, 2011, p. 1309). Moreover, scholars have highlighted the competition for access to "good" schools and how it shapes the city by intensifying sociospatial segregation (see e.g., Noreisch, 2007; Warrington, 2005; van Zanten, 2005). Education is of increasing importance for middle-class parents' decisions of where to live (Butler \& Hamnett, 2011a, b). Affluent parents buy into areas that provide the "highest-performing" schools, thereby pushing housing prices significantly higher in neighborhoods with popular schools (Cheshire \& Sheppard, 2004; Gibbons \& Machin, 2006). ${ }^{1}$ Although the respective researchers already point to the interconnectedness of local settings and education, they have somewhat stayed "outside the school gates" by focusing on access to schools in different neighborhoods rather than on what happens inside schools in different local settings (for an exception, see Lupton, 2004, 2005). So far, scholars have thus not sufficiently analyzed whether schools work differently in different socioeconomic neighborhood settings.

In this chapter, I address this gap (see also Nast, 2020). Based on ethnographic data and in-depth interviews with teachers and parents at two primary schools in Berlin, Germany, I argue that local neighborhood settings and educational provision interact. Combining a Bourdieusian approach with new-institutional organizational theory, I understand organizations as fields. Based on this, I empirically analyze how local neighborhood settings become important as social, symbolic, and administrative units and structure these fields - and thus organizational practices.

\section{A Theoretical Approach: Organizations as Fields}

Conceptualizing the interplay between organizations and local settings requires an understanding of organizations as open systems that do not simply operate according to internal rules, logics, and demands. Rather, following new-institutional theory, I understand organizations as significantly impacted by institutional pressures external to themselves. Although institutions and organizations are often used interchangeably in everyday speech, proponents of a new-institutional approach define institutions as broader cultural, legal, and political contexts, such as laws, curricula, or professional standards (DiMaggio \& Powell, 1991; Frumkin \& Galaskiewicz, 2004, p. 283). These become institutionalized as they shape the modes of cognition,

\footnotetext{
${ }^{1}$ Others have shown that, historically, middle-class families are not the only ones to have moved for the 'right' school; schools have also established themselves in areas that help them to maintain and reinforce a prestigious position within the "field" of schools (Gamsu, 2016).
} 
taken-for-granted scripts, rules, or schemas of actors within the organization. Neoinstitutionalists have thus mostly focused on how processes of institutionalization result in uniform organizational reactions. DiMaggio and Powell (1983) describe this similarity as institutional isomorphism, of which they distinguish three forms: coercive, mimetic, and normative. The first, coercive isomorphism, results from political influence and the pressures of legitimacy and cultural expectations, which collectively push organizations in certain directions - towards affirmative actions or processes of state-led standardized reporting mechanisms, for example. Mimetic isomorphism stems from processes in which organizations "copy" solutions to organizational problems from other organizations. Finally, normative isomorphism is associated with professionalization. Professionals are involved in networks and study at training institutions such as universities, where they absorb common normative rules about professional behaviour. These then diffuse through professional networks and ultimately make organizations very similar (DiMaggio \& Powell, 1983, pp. 150-154). For new-institutionalists, schools in different neighborhoods thus work similarily due to similar institutional pressures which are-in this perspective-much more important than local settings (see e.g., Arum, 2000).

Yet, similar institutional pressures might have different effects in different neighborhoods. To develop a more context-sensitive approach to how institutional pressures, local settings, and organizations interact, I combine the new-institutional approach with the Bourdieusian field concept. The idea of organizations-as-fields (Emirbayer \& Johnson, 2008) becomes crucial here. Following Bourdieu, a field is a network of objective relations between different positions, objectively defined by the distribution and forms of capitals (Müller, 2002, p. 167). Such fields are hierarchically structured with dominant and subordinate positions, based on the volume of resources agents possess in relation to the other actors in the field (Naidoo, 2004, p. 458) —or in the organization. Within these fields of social positions, "struggles or manoeuvres take place over resources, stakes, and access" (Bourdieu, 1980/1990; cited in Everett, 2002, p. 60). Moreover, organizations-as-fields are also positioned in relation to other organizations in so-called organizational fields. Schools do not work in isolation from other schools and must position themselves in relation to each other, by competing for students and possibly also funding. Organizational fields are thus fields of objective social power relations in which position-taking and struggles over resources take place (Bourdieu, 1972/1977; Bourdieu \& Wacquant, 1996). Taking these objective power relations into account reveals that the effect of institutional pressures may differ depending on the objective power positions within an organization as well as its relation to other organizations. Organizations can thus be best understood as specific field-constellations, in which institutionalized pressures, the objective power structures within the organization, as well as its position within a field of organizations interact. In the remainder of this chapter, I build on these positions to ask if and to what extent field-constellations of schools vary by neighborhood setting. 


\section{Methods}

I draw on ethnographic observations and interview data from two organizational case studies in two neighborhoods in Berlin, Germany (see also Nast, 2020). I compare two schools that are similar in size, have multi-grade classrooms, and according systems of teaching, as well as (optional) after-school supervision, but that vary in regard to their local context: One is located in a deprived, "super-diverse" (Vertovec, 2007) neighborhood and the other in an affluent, mostly white, neighborhood. I focus on primary schools, as - in contrast to high schools - they mostly draw children from their immediate local environments.

The primary school in the deprived, "super-diverse" (Vertovec, 2007) neighborhood is located in Cross-Square, ${ }^{2}$ one of Berlin's inner-city neighborhoods. As can be seen through data from the Senate Department for Urban Development and the Environment in Berlin, Cross-Square has a much higher than average level of unemployment as well as numbers of individuals younger than 15 receiving additional state financial support, an indicator of child poverty (Häussermann, Werwatz, Glock, Dohnke, \& Hausmann, 2011, p. 9). These metrics are also reflected in CrossSquare's primary school: Over $90 \%$ of pupils qualify for free school supplies and approximately $90 \%$ do not speak German as their first language. Many of the more highly educated parents purposely avoid this school, by moving away or by manipulating the catchment system. The school in the privileged neighborhood is located in Roseville, a typical white middle-class neighborhood with a suburban feel. According to data from the Senate Department for Urban Development and the Environment, Roseville is one of Berlin's privileged neighborhoods: Unemployment is much lower than average, many families in the neighborhood own single-family homes, and additional public support for children younger than 15 is lower than the Berlin average (Häussermann et al., 2011, p. 9). Only $2 \%$ of children in the Roseville school qualify for free school supplies and 7\% do not speak German as their first language. Most of these children come from highly educated families and only a few are early learners of German.

To gather rich data, I conducted five to six months of (participant) observation in each school, averaging three days per week to complete approximately $870 \mathrm{~h}$ of fieldwork from July 2012 to June 2013. I also conducted semi-structured interviews with parents and teachers from within the organization as well as with a smaller sample from other schools (52 interviews in total). Interviews lasted between 20 and 100 minutes. When interviewing teachers, I covered their work biography, the school's clientele, day-to-day work, their relations with parents, changes to working conditions, as well as their professional identity. With parents, I focused on their children's academic trajectory, their experiences in school, and how they define their role in their children's education.

${ }^{2}$ I have anonymzed both neighborhoods and schools throughout this chapter. 


\section{How Neighborhoods Shape Organizations-as-Fields}

How do local settings structure organizations? In the following, I will show based on the empirical material how neighborhoods become important as context-specific conditions interact with institutional pressures to produce localized fields. Neighborhoods structure this interrelation between institutional pressures, as well as the objective power relations within as well as between organizations. Three aspects are of importance here: First, neighborhoods become relevant as social units by structuring the social composition of children and parents. Second, neighborhood settings come with symbolic meanings that position schools in a citywide field of education. Finally, local settings function as administrative units that structure the institutional embeddedness of schools-depending on the local context, schools face different regulations, programs, and funding schemes. I will further develop each of these aspects in the following.

\section{Neighborhoods as Social Units: Power Positions and Institutional Pressures}

As I have shown above, researchers of social composition have argued that a crucial difference between schools in privileged and deprived neighborhoods lies in their social clientele. Although researchers have shown that social (and ethnic) segregation within schools is often higher than within a given neighborhood (see Fincke \& Lange, 2012 for Berlin; see Johnston, Burgess, Wilson, \& Harris, 2006 for the UK), there is a clear relationship between a neighborhood's social composition and that of its schools. However, scholars have paid little attention to how this structures schools-as-fields. Rather, they have conceptualized the effects of social compositions mainly by focusing on the behavior and learning attitudes of children. Others have highlighted that family-school relations differ depending on the school's social composition (Lareau, 1987; McNamara Horvat, Weininger, \& Lareau, 2003; Vincent, 1996). Scholars have shown that parents' cultural capital impacts parental involvement and its perception (Crozier, 2000; Lareau, 1987, p. 81). The same is true for parents' social capital: McNamara Horvat et al. (2003, pp. 320, 327, 331) highlight how the resources available through parental networks vary by social class. Overall, middle-class parents tend to hold schools and teachers accountable more often; working-class parents are more likely to trust the professionals (Crozier, 2000). Although these accounts provide important insights of how involvement varies by class, researchers often focus on how this advantages individual children vis-à-vis the school. In the follwing, however, I will focus on how different social compositions more generally produce very different structural contexts, in which educational professionals work. 


\section{Powerful parents, powerful teachers?}

Depending on the neighborhood, parents often possess different forms of capital which shape their objective positions within schools-as-field. As I described above, Bourdieu argues (1997/2000, p. 183) that a field is characterized by a network of objective relations that are defined by the resources that actors possess in relation to each other. The positions of teachers and parents thus cannot be understood per se but differ between neighborhoods. These different social positions have important consequences for the kinds of institutional pressures that parents are able to "activate."

\section{Roseville: Institutional pressures in a field of powerful parents}

In Roseville, structurally, parents are powerful actors. Most parents bring high amounts of cultural, economic, and social capital (Bourdieu, 1986) to the school-asfield. Their power position, however, operates in subtle ways. If asked, parents in Roseville describe their relationship to teachers as very positive. Interactions are friendly and parents are often very supportive of the school. That said, parents also underline that they have clear expectations "that things in school will be $100 \%$ [...]" (Parent interview 15).

Parents constantly implement these expectations in the field by reminding teachers of their demands-with different levels of intensity. If parents are concerned by the grading process, the cancellation of classes, or a particular teaching style, they often react by being more present at the school, thereby signaling that they are observant of what is going on. Parents might sit in on lessons, ask about the rates of sick leave or critically comment on cancelled lessons during PTA meetings. Brigitte, an energetic public prosecutor, explains:

I guess it's pretty exhausting for teachers here <laughs $>$, because, yes, everybody [...] supports the school $[\ldots]$ but I think very often, even with trivial things, parents always comment on it, or look into it further and inquire [...] parents have very high expectations of $[\ldots]$ what the school has to provide. (Parent interview 17)

However, if these interventions do not bring about the desired result, parents can also escalate the situation, as the following anecdote reveals:

C. Scherk, the vice-principal, and I are making our way to the principal's office. Two women are waiting outside the office. [...] They would like to discuss the grading procedure in German. Many of the children had disappointing results and the parents found the grading process somewhat suspect. C. Scherk smiles, but explains that they would have to discuss this another time. We enter the office and behind the closed door, she explains that she does not want these mothers to look at the school's grading rules. Once they get hold of it, they will complain about every single test. A few days later, however, C. Scherk tells me that "the parents" have now officially complained to the local authority. They were unhappy with how the school dealt with their questions and P. Deuft, the school principal, was advised to make the grading more transparent. (Author's field notes, Roseville primary school, January 11, 2013) 
Parents can thus ensure that their own expectations are taken into account by "activating" external institutional regulations. In signaling to the local school authority, they introduce a form of coercive isomorphism (DiMaggio \& Powell, 1983, pp. 150-151) that would not have been present otherwise. This highlights the need to conceptualize the role of institutional pressures together with local context. In Roseville, parents know how to "play" the game and can make use of their position to pressure the school. Actors' ability to involve themselves in such "struggles or manoeuvres [...] over resources, stakes, and access" (Bourdieu, 1980/1990; cited in Everett, 2002, p. 60) depends heavily on their position within the field. Parents are themselves quite aware that specific resources are needed to deal with the school, as Heike, a middle-class stay-at-home mother, emphasizes:

I think we have to make sure to push our requests in a way that it's heard by the school [...] it's helpful to find parents, personalities, who know how to gain recognition $[\ldots]$ off the top of my head, I'm thinking of lawyers <laughs $>$. (Parent interview 16)

However, parents' powerful position in the school goes beyond the actual control of specific situations (such as when parents are unhappy with teachers), as Lareau and others have put forward (Lareau, 1987; McNamara Horvat et al., 2003). Parents do not exclusively intervene when something "goes wrong"-although they do so as well. Their presence means more than that: In a subtler way, parental beliefs of what schools are expected to provide can be understood as an institutional pressure. In Roseville, parents constantly implement their expectations in their daily practices and are in a sufficiently powerful position to pressure the school to comply with their wishes. This does not mean that parents in Roseville always "get their way," but they do shape the school-as-field by constantly reminding teachers, the principal, and other educational professionals that, in theory, they could organize and thus position themselves in opposition to the school. This creates much more subtle forms of control, which go beyond the idea of middle-class parents "ridding" schools of "bad" teachers (see e.g., Kahlenberg, 2003, p. 62). Rather, parents structure the field by making sure that they are implicitly present in teachers' assumptions and daily understandings of their work, as this teacher explains:

You can always count on the parents [...] BUT you also have to reckon with them, that means, if you have to write a letter to the parents, you'd better think twice how you formulate it $[\ldots]$ you need to make sure to fulfil all the educational standards. (Teacher interview 19)

\section{Cross-Square: Institutional Pressures in a Field of Powerful Teachers}

The situation in Cross-Square is profoundly different: Parents are less successful in shaping the school-as-field. Due to their social position within the field, their ability to successfully involve themselves in controlling the school and to implement their expectations is limited. They thus have to find other ways of assuring their child's wellbeing in school. 
Parents thus often highlight their own role in their children's education rather than demand that the school performs differently. As several parents in CrossSquare explain - if your family "is all right" and is "working hard," the school does not really matter. Moreover, in an attempt to work against "the very bad reputation of our Cross-Square" (Parent interview 2), many parents highlight that the school is actually better than often assumed. Seeing the school as bad is understood as a confirmation of the ethnic and social stereotype held by (middle-class) people from outside of Cross-Square. Constructing the school as "good" becomes an important way of challenging this stereotype. Skeggs (2004) has argued that working-class women are well aware of the judgments of "the dominant" and use respectability to establish symbolic value (see also McNay, 2004). To do so, it is important not to complain about the school; respectability is attained through the individualizing narrative of "it is all about your family" instead of by giving voice to problems and questions of quality. To discuss structural problems is sometimes even understood as an insult:

The [PTA] meeting takes place in the assembly hall [...] 25 people have shown up, filling some, but not all of the rows of chairs that are facing the teachers' table. The discussion goes on in Turkish. [...] After the presentation, two mothers explain what happened. A grandmother had said that the school was "bad" and a "ghetto school" and that she was really unhappy to send her grandchildren there. Other parents reacted very angrily, offended, and shocked. One of the mothers explains: "It's disgusting, how can she say such a thing about our neighborhood and our school?" (Author's field notes, Cross-Square primary school, November 1, 2012)

This hesitation to raise problems can make it hard for parents to find support for their concerns. Moreover, teachers often support an individualizing view, pushing parents to "take responsibility." As Zehra, a working-class mother with a migrant background, who works as a doctor's assistant, recounts: "The teacher explained that it depends on the parents, that we need to work with the school and support the school and that everyone can then make it!" (Author's field notes, Cross-Square primary school, November 1, 2012). Although the image of "this is a bad school" is challenged here (at least verbally) (Skeggs, 1997), this comes at the price of individualizing the structural inequalities as well as the school's responsibility.

Following this pattern, many parents invest heavily in displaying how "supportive" they are of the school, and in presenting themselves as "good" families-something that might be best understood as a form of "moral capital" (Valverde, 1994) that becomes especially salient when economic and dominant forms of cultural capital are less accessible. Parents will state their satisfaction with the school in front of the teachers: "We are lucky [that our child is in her class]" (Author's field notes, Cross-Square primary school, August 27, 2012). A prominent location for "good parenting" is the PTA meeting. As A. Hellwig, an experienced teacher, explains with a laugh: "The point of the PTA? Allowing parents to show that they're interested" (Author's field notes, Cross-Square primary school, August 28, 2012). This clearly demonstrates the difference between the two schools: Although Roseville teachers are often slightly afraid of PTA meetings, because they must justify their teaching practices, in Cross-Square, the PTA meeting is the place where 
parents have to prove that they are indeed "good" parents. In Cross-Square, parents often have no alternative to complying with the school's expectations-rather than the other way around.

The fact that some parents highlight their own role in the educational process does not mean that the parents are never unhappy with the school, or do not voice that the school is treating them or their children poorly. Yet even very unhappy parents are often unsuccessful in pushing for change. Due to the parents' less dominant forms of cultural, social, and economic capital and their resultant position in the field, teachers in Cross-Square deal with parental demands very differently than in Roseville. Evin, a working-class mother who had moved from Cross-Square to Roseville a year earlier, explains the difference:

We are sitting in a classroom and Evin tells me how in the old school in Cross-Square, a lot of parents actually complained about the school as well. Eventually, however, they realized that even if they scheduled appointments with the teachers or complained to the principal "nothing changed." After a while, Evin says, this became "so frustrating that they stopped trying to get involved." She shakes her head slightly while she remembers. In the new school, by contrast, parents always seem to know what to do, they have powerful networks and "if they are unhappy, they make sure that things will change $[\ldots]$ and it will work." (Parent interview 24, author's field notes)

Parents' social positions not only often leave them without leverage against the school, but they also have a hard time finding other people to support them. As I laid out above, Roseville parents often rely on the local school authority as the next level in the hierarchy; they also contact external experts (see also McNamara Horvat et al., 2003, p. 334; Lareau, 1987). In contrast, parents in Cross-Square ask other professionals in the school for help, which is often less effective. Even if teachers also question the competencies of a specific colleague, struggling teachers are at the same time seen with sympathy and personal relations make it hard to intervene on the children's behalf.

This dynamic creates very different structural conditions for teachers in CrossSquare than in Roseville. Although individual teachers in Cross-Square obviously differ, they have a general tendenc to view parental concerns as neither "threatening" nor "urgent". In Cross-Square, teachers do not fear parents as powerful actors in the school-as-field and they are thus less often part of their everyday deliberations. As a teacher explains:

The advantage of working at our school is the parents [...] not like at a school in Roseville, [...] [where] Mr PhD and Ms Professor bring in their diamonds, and you, as a teacher [...] have to justify and explain yourself constantly. (Author's field notes, Cross-Square primary school, August 16, 2012)

Expectations of what a school should provide are thus less powerful in CrossSquare. Again, this highlights the importance of the interplay between local context and institutional pressures for understanding how both structure schools-as-fields differently. 


\section{Social inequality, institutional pressures, and the question of the meritocratic myth}

The social composition, however, not only shapes the field by introducing different objective power positions; social inequality also impacts schools by shaping the opportunities available for the realization of broader cultural expectations of what schools should achieve in order to be legitimate, as well as for measuring up to teachers' own expectations.

Cross-Square: Institutional conflicts within the field

In Cross-Square, latent antagonism in the field of education become manifest. The school-as-field is characterized by a social inequality that cannot be solved at school but continues to interfere with its institutionalized aims. The meritocratic promises inherent to teachers' profession-what new-instutionalists term normative pressures (e.g., DiMaggio \& Powell, 1983, pp. 152-153) — and to the educational field as a whole, namely that everybody has the same opportunities in school, are challenged here. In a deprived neighborhood like Cross-Square, this institutionalized expectation constantly meets a reality that does not fit.

Cross-Square children often enter school with very few school-relevant skills and little preparation, while living under difficult structural conditions. Teachers work with students whose families struggle, often due to the low-level of state support for welfare recipients, to provide for their children, to invest in new clothes, or to find a space where children can study at home. Children often lack basic materials, such as scissors or pens, to fully participate in the lessons. Teachers regularly compensate for this by buying such supplies for at least some of the children in their class. In other instances, parents struggle with addiction or psychological issues linked to poverty, and accordingly have a difficult time supporting their children. Expectations, such as studying for school at home, often seem simply unrealistic within the given conditions.

As a result, children frequently do not progress as expected. Teachers regularly speak of "despairing" of their students' learning process: "It's exasperating [...] I did all these diagnostic tests in math [...] but they even struggle with counting, they just don't know how to do it" (Author's field notes, Cross-Square primary school, November 6, 2012). As B. Speicher, a teacher who now works in Roseville, recalls while reflecting on her time in a neighborhood like Cross-Square: "If I wanted to see the futility of my work, I just had to ask after a lesson-come here and tell me what you've learnt! And often, they really had no clue at all" (Teacher interview 21).

Many teachers explain that most of their students are "behind," "weak," or "very slow learners" (Author's field notes, Cross-Square primary school, August 22, 2012). This becomes especially pressing when the teachers consider what students should be learning, at least in theory: 
[T]here is the core curriculum that we HAVE to cover and the students go on to secondary school and, well, there are certain things that will be expected of them [...] but, well, it is difficult, it is not doable, to be honest! (Teacher interview 6)

Although most teachers are aware that many of these problems are due to the structural inequality under which the children grow up, they still feel helpless in their attempts to productively address them. The field is thus characterized by a mismatch between the institutionalized expectation that every child be provided with the same opportunities - and that schools can compensate for social inequality-and the teachers' day-to-day experiences. With the social composition of the neighborhood comes a constant challenge of if schools can actually help to overcome structural inequality and function as legitimate organizations. As newinstitutionalists have argued, organizations adapt to institutionalized pressures in order to "be acknowledged as legitimate and reputable" (DiMaggio \& Powell, 1983, p. 153). In Cross-Square, the field is thus not only structured by weaker parental control, but it is also harder to meet general expectations of what schools should achieve.

\section{Roseville: Avoiding conflicts within the field}

In Roseville, the situation is clearly different. The school-as-field is localized through privilege rather than through inequality. Accordingly, there are fewer obvious internal contradictions within the educational field. Children are already equipped with many of the competencies they are expected to acquire in school. For teachers, the task that they set for themselves as professionals is much easier to achieve. Although not without its frustrations, there is considerably less exhaustion than in Cross-Square.

As in Cross-Square, Roseville teachers are well aware that their students' social background is an important factor in shaping their work. Professionals describe the students and their families as coming from the "educated classes" and "the upper crust" (Teacher interview 20). Teachers clearly see the advantage of these structural conditions for their classroom instruction: "Children have surroundings that make it easy for them, they get a lot of support from home [...] and well, yes, I would say when it comes to the students, teaching here is really easy" (Teacher interview 26).

Moreover, although often unaware of it, teachers also rely on the support system that children receive at home. The school is thus structurally much more likely to fulfil the institutionalized expectations of what a school should achieve-partly because of the "invisible" work that is done by the parents, but rarely discussed in school. The prevalence of traditional gender arrangements, especially of stay-athome mothers, plays an important role here. Parents regularly help their kids study: "Well, I'm pretty sure that [...] most parents, independent of what they say, help their children with homework,[...]" (Parent interview 21). Parents become especially involved if a child is in danger of falling behind. Harald, a middle-class father 
who works in a bank, proudly explains how his family has tackled his son's difficulty adapting to the first grade:

In math, we really made up for his difficult start, and now, we can say that he really caught up with the group $[\ldots]$ and, well, he's not there yet in German, but thanks to the support here at home, he will catch up. (Parent interview 14)

Parents have different reasons for helping their child at home, from assuring success to spending time together and learning more about their child's school experiences. Whichever the reasons, parents crucially shape schools-as-fields by helping the school to succeed. These often informal (AlSayyad, 2004, p. 10; Roy, 2011, p. 233) practices are important as they help to fulfil the institutionalized meritocratic myth by veiling the additional effort parents engage in and thus obscuring the limits of what can actually be achieved only in school, especially in comparison to CrossSquare. Some teachers are aware of these limits and struggle with how to deal with them:

It is complicated for me as a teacher [in terms of the grading], because I can see [...] if parents helped; but if parents help, it also helps the children to learn, and I can't forbid it. Also, I can't punish children for having supportive parents. (Author's field notes, Roseville primary school, May 15, 2013)

Others comment ironically on the "fake" character of their experienced success: "We have children, they pass through here, you can be dumb as a teacher and the children will still learn" (Teacher interview 26); "you don't need training to teach here" (Teacher interview 23); "you can hardly prevent these children from learning" (Teacher interview 21). Nevertheless, it is easier for Roseville teachers to ignore these limitations than for Cross-Square educators to bear the sense of failure they experience.

Interestingly, the conflict within Roseville's educational field is somewhat the opposite of that in Cross-Square: The quasi-automatic ability of students to learn also poses a challenge to the meritocratic assumptions of teachers; however, this conflict is much easier to hide than in Cross-Square. Thus, in Roseville, the social composition that comes with the neighborhood as social unit not only implements greater parental control, but also makes it easier for the school to succeed as a legitimate organization (DiMaggio \& Powell, 1983; Meyer \& Rowan, 1977) that is seemingly able to fulfil the institutionalized expectation of advancing the education of all children.

\section{A Neighborhood's Symbolic Meaning as Institutional Pressure}

Neighborhoods also shape schools-as-fields through their symbolic meanings. The dominant understanding of what a neighborhood symbolizes is significant for its position in the spatial stratification of a city (Blokland, 2009; Logan \& Molotch, 1987). Although researchers have mostly discussed a neighborhood's reputation in regard to parents' schooling choices (Ball \& Vincent, 1998), I argue that these 
images are also relevant for how schools-as-fields get structured and are thus of relevance for the professionals working in such local organizations. As such, neighborhoods' symbolic meanings can be understood as institutional pressures that structure local organizations.

Both Bourdieu (1987) and Butler (e.g., Butler, 1997/2001) have highlighted the importance of such forms of symbolic power. Following Bourdieu, the term symbolic violence describes the experience of being categorized according to the symbols that the dominant class understands as legitimate, while having "little choice about whether to accept or reject" these categorizations (Bourdieu, 1987, p. 812). In contrast Butler, in the post-structural tradition, sees domination as part of every categorization, as it forces the individual to perform to categories; she acknowledges that hierarchies in the social positions from which people speak can have different impacts (Villa, 2011, p. 59). Following these insights, it is important to highlight how the symbolic hierarchy of the spaces in which teachers work differ completely depending on the neighborhood. These symbolic meanings are invariably contested (Massey, 1994) and conflicting readings of a neighborhood can coexist (Blokland, 2009). Nevertheless, most teachers related to a dominant symbolic meaning of privilege in Roseville and deprivation in Cross-Square. As such, teachers themselves engage in symbolic work and institutionalize their neighborhoods' meanings by implementing or challenging those in their practices.

\section{Cross-Square: A neighborhood's meaning as symbolic violence}

The Cross-Square school is positioned in a neighborhood that can be described, akin to other neighborhoods with similar structural conditions and symbolic (institutionalized) meanings, as "profoundly stigmatized, poverty-stricken, and ethnically marked" (Paulle, 2013, p. x). In the German public discourse, deprived neighborhoods are often described as a sozialer Brennpunkt, a "social hotspot" with high poverty, crime, and conflict. Many teachers use this neighborhood categorization - rather than the school - to explain their daily experiences. Most Cross-Square teachers have experienced some form of symbolic violence as various (often powerful) actors, such as the local school authority, middle-class parents, or other organizations, constantly label them and their school as undesirable, in reference to their location in a sozialem Brennpunkt. Several teachers told stories of how acquaintances reacted when they learnt where they worked. Notably, the neighborhood acted as one of the most important signifiers. A. Hellwig, an experienced teacher, describes:

If I'm on holiday, and I travel and you meet new people and if I tell them I work as a teacher, that is very respected, it is a respected profession, but if I then say primary school and Berlin, well, then people are already like "uhhh" and if I then go on and tell them I work in Cross-Square, then everybody goes like "oh, poor you ..."- and that makes me very angry, and I always try to explain [...] but no one sees what great work we do here and how great our kids are. (Author's field notes, Cross-Square primary school, June 13, 2012) 
Often, teachers feel that they are labeled negatively independent of what they actually do, and describe their powerlessness against the symbolic meaning of their workplace. Thus, they often see no escape from the stigma of being part of a primary school in a "bad" neighborhood-as E. Holstein, the principal, explains: "As a school, well, sometimes I guess we just have a label and it is really hard to work against that" (Author's field notes, Cross-Square primary school, August 21, 2013).

Moreover, teachers also experience the school's devaluation in interactions with other members of the educational field. Often, secondary schools signal their preference not to have students coming from Cross-Square. When the school organized an informational evening at which secondary schools could present themselves, the visiting principals generally highlighted that they were looking for "high-achieving" students-implying that such students were not to be found at Cross-Square. E. Holstein, the principal, explained that the Gymnasium initially did not want to show up at all- "they are paralyzed by their own arrogance" (Author's field notes, Cross-Square primary school, November 27, 2012).

Moreover, middle-class parents signal Cross-Square primary school's undesirability to teachers, especially during enrolment periods:

A. Hellwig tells me about a mother [...] with an academic background [who] called up the school, as she was unsure if she really wanted to send her son there. [...] A. Hellwig invited her to come to her classroom [to observe the lesson], as she is convinced of the school's work [...] This mother, then, did come by, but never got back to A. Hellwig: "In the end, you know, realistically, she won't send her child here. You know sometimes that makes me so sad, this attitude, it is the image of Cross-Square!" (Author's field notes, Cross-Square primary school, August 30, 2012)

The mother, at least in A. Hellwig's retelling, is not rejecting the school per se, but rather Cross-Square as a neighborhood and the assumed conditions that it entails. Thus, the school's actual work seems unable to change the general perception linked to the neighborhood.

Teachers have different ways of dealing with these images. The interplay of enacting, recreating, and challenging institutionalized pressures is part of the process of institutionalization: Some acknowledge that they themselves would not want to send their children to Cross-Square. Others argue that schools in Cross-Square are in general "no good" and that it is maybe even wrong to keep talented students at the school. Some are straightforward, linking the neighborhood to unsuccessful school trajectories, as F. Hoff explains:

I have to say, with those students, for whom I see a chance, even a small one, I make sure to send them OUTSIDE of this borough, outside of Cross-Square, to Mosthaus [a more middle-class neighbourhood] at least [...] they have a different clientele there $[\ldots]$ and even if our students don't make it there, if they leave school after 10th grade, but are coming from there, it's different! (Author's field notes, Cross-Square primary school, December 7, 2012)

Others argue that the external judgments are mistaken and that the school is actually better than assumed-or at least that for them a school in a neighborhood like Roseville would be "too boring" and "not challenging enough" (Teacher interview 11; Teacher interview 10). Although teachers do experience forms of symbolic violence and devaluation, they also engage in practices of accruing value for 
themselves. Structurally, they nevertheless face symbolic devaluation as part of their daily duties.

\section{Roseville: A neighborhood's meaning as symbolic valorization}

These symbolic processes are similar in Roseville, yet at the opposite end of the field. Here, the school is positioned in a neighborhood that is characterized by relatively high social status. The school's position at the top of the educational and geographical field is signaled to teachers and the symbolic meaning that comes with it shapes the school-as-field as a form of institutional pressure. In contrast to CrossSquare, the school is constantly termed a desirable organization. Similar to CrossSquare, however, that perception is not necessarily connected to the school's lived reality. Rather, Roseville's positive symbolic meaning as a neighborhood engenders the quasi-automatic assumption that a school in this location provides high-quality teaching.

This positive perception also becomes apparent in how teachers describe their work: Many point out that they are "VERY lucky" (Teacher interview 18), often directly comparing themselves to neighborhoods like Cross-Square. One teacher, B. Speicher, describes her own journey through the educational field as finally being "on the bright side for once" in Roseville (Teacher interview 21). Being on the bright side, however, is not so much linked to the specific school, but to the assumptions that are linked to Roseville as a neighborhood.

Roseville's high symbolic status also becomes apparent in the school's relation to other members of the educational field. Teachers have a clear understanding of their position in an exclusive network of schools in Roseville-and children often move on to "other schools with very good reputations in this neighborhood" (Teacher interview 26). Teachers also express the high status of Roseville's primary school in how they talk about other schools-including those located in neighborhoods like Cross-Square. Working in Roseville is seen as a completely different and preferable experience: "None of our teachers would voluntarily work in CrossSquare" (Author's field notes, Roseville primary school, May 16, 2013).

Parents also signal Roseville's desirability to the teachers-especially during enrolment periods when demand usually exceeds the number of spaces available. Once the enrolment acceptance letters are sent out, the phone regularly rings with parents inquiring if their children "made it" (Author's field notes, Roseville primary school, January 16, 2013). Stories abound of parents who desperately want to send their children to Roseville's primary school, write letters to the principal, and promise to be very engaged in school matters. Parents also make use of informal strategies to assure access. P. Deuft explains:

Parents often try to make deals so that we will accept their child, they bring their child's CV, or they say they have a holiday home at the Baltic Sea where they would be happy to welcome children from the school if we would accept their child—basically they ask: "What can we do to get our child enrolled here?" (Author's field notes, Roseville primary school, January 11, 2013) 
As school enrolment in Berlin is still mostly organized by catchment area and the city educational authority decides the granting of exceptions, these strategies are only partially successful-and, according to official documents, not an option to begin with. Nevertheless, demands voiced by the parents shape the field by producing symbolic structures that signal a constant valorization of the school.

This is very much linked to the neighborhood of Roseville, which acts as a kind of guarantor for a good school. Parents often describe how they explicitly moved to Roseville because of its (excluding) "educational field":

We moved here, among other things, because we knew that schools are better in this neighborhood. It was not especially Roseville's primary school, but more generally, schools as such are better here. [Why?] Well, on the one hand, because it's a well-off neighborhood and schools in such contexts often have better facilities and equipment, and, well, at least in my case, the other reason is the fact that there are no so-called problem kids in these privileged neighborhoods or at least not as many as in other neighborhoods. (Parent interview 19)

Finally, teachers in Roseville are also aware of these symbolic structures and generally share them. Still, as in Cross-Square, some teachers at Roseville primary school also challenge their school's dominant image-namely the superiority of their organization. Some teachers voice concerns about the pressure that children are under or wonder if parents might be too involved in children's academic trajectories. Despite such occasional doubts, the neighborhood's positive symbolic meaning shapes the school-as-field through strong symbolic valorization, and questions of the legitimacy of teachers' work are far less challenging in Roseville than in Cross-Square.

\section{Neighborhoods as Administrative Units: Projects and Institutional Embeddedness}

Finally, besides the social and symbolic processes connected to the neighborhood, neighbourhoods also becomes important as administrative unit.

This is closely linked to changes in institutional regulations and in the allocation of public resources that have taken place in recent years. Some have captured these changes as a new form of urban life under capitalist and neoliberal regimes (Amin \& Thrift, 1996; Harvey, 2005; Wacquant, 2008), others have put forward less radical interpretations. Either way, these dynamics also become visible in Germany's educational field. In response to various reforms, such as the implementation of "allday schools" and continually tight state budgets, schools are increasingly perceived as being in need of partnerships with non-school actors, such as NGOs, public organizations, and private charities that offer projects, support, or counseling for children and families (Baumheier \& Warsewa, 2009, p. 20). Scholars have understood these changes as a new form of educational governance (Freytag, Jahnke, \& Kramer, 2015, p. 67; see also Duveneck, 2016). Although the landscape of institutional 
regulations has thus changed to some extent for all schools, these processes still vary by neighborhood.

\section{Cross-Square: Additional workload, institutional pressures, and types of cooperation}

Funding cuts hit somewhat harder in Cross-Square than in Roseville, despite the additional, compensatory funding that the Senate allocates to schools in socioeconomic contexts such as Cross-Square. Teachers describe how a lack of time makes it harder for them to meet the needs of their students, especially as students' range of abilities is often vast.

On top of this, current institutional changes put the school under increasing pressure to open itself up to external partners, such as NGOs, foundations, and public institutions. This comes with an additional workload that at times seems unmanageable. The school is working on a wide range of topics by engaging in cooperation and projects, such as child protection, nutrition, multilingualism, integration, conflict resolution, family counseling, homework tutoring, and the improvement of parent-school relations. As schools in contexts like Cross-Square are often seen as unsuccessful, the pressure to be "active" can be especially strong. Newinstitutionalists have argued that this need to assure legitimacy can push organizations to employ measurements even if they do not seem to be of direct help for their daily work (Meyer \& Rowan, 1977). Although teachers are indeed sometimes critical of projects and partly see them as "keeping them" from their principal duties, the school as an organization must yield to the pressure in order to signal that it is doing "all it can" to come to terms with the problems often linked to it.

Moreover, external actors continually ask the school to participate in programs and projects. NGOs, public and private agencies, and foundations regularly offer to cooperate with the school, due to its position at the bottom of the educational and geographical field, where many organizations expect to find their target groups. As E. Holstein, the head of the school, explains: "You know, the school is the main platform for all kinds of actors and organizations, because, well, as we have compulsory school attendance, we have most contact with parents and children!" (Teacher interview 27)

Cross-Square's local authority also pushes the school to develop partnerships with kindergarten and secondary schools in the local area, as well as with the childwelfare agency. To assure, for example, a smooth transition from kindergarten to primary school, schools are asked to liaise with local kindergartens. The CrossSquare school works with six different kindergartens, invests in its relationships with secondary schools, and also cooperates with the child-welfare agency. A teacher is assigned as contact person for all issues linked to the agency and regularly meets with a caseworker.

In addition, certain policy programs that are meant to address inequality require additional tasks that are not present in neighborhoods like Roseville. The "Bildungsund Teilhabepaket" ("Education and Participation Package") entitles children 
whose families are on welfare to additional allowances for costs such as school trips, school lunch, learning materials, and additional learning support. In CrossSquare, families regularly take advantage of this 'package,' but it requires the school to complete a lot of administrative work. Another example is the program "Districts with Special Development Needs-The Socially Integrative City," instituted to target deprived neighborhoods in Berlin. Neighborhood councils were implemented that often explicitly work to facilitate networking between the various actors who work on education in the neighborhood and also fund small projects within the schools. These push-factors and the additional funding are only present in deprived neighborhoods and thus vary locally.

As a result, the number of projects and partnerships in Cross-Square is very high. The principal at a school in a similar neighborhood summarizes the situation as follows: "If I were to meet and sit down with everyone who somehow works in the school here, if I were to sit down with all of them once a week, I would be doing nothing but sitting in meetings" (Teacher interview 6).

Yet not only the quantity of partnerships but also the types of cooperation increase the workload. The school is often involved in projects that are only temporarily funded. Even if projects are successful, permanent funding is rarely available and the school must regularly apply for fresh funding. Moreover, funding streams rarely provide for funds to organize, apply for, and audit such projects. Hildegard, a politically engaged mother and lawyer, explains:

The teachers can't complete all these tasks, I think it takes so much energy and time, you need to write a proposal here, an application there, and tons of additional meetings [...] and then, on top, you also have to network with kindergartens and secondary schools, to share experiences, but they don't get additional hours or compensatory time-off for any of this [...] they have to do all of this on top [of their teaching], and we haven't even started to talk about preparing lessons! (Parent interview 12)

This often creates a dilemma: Additional funds would be useful but the workload that the application and auditing process entails creates a situation wherein it is almost irrational to apply, as E. Holstein explains:

We stopped applying for money from the neighborhood council because, you know, the application process is so complicated, it requires so much time and energy, we can't do it anymore, it's just not possible and it's unfortunate and sad because, you know, there is money, but you can't take it because it's just too much work to do it! (Teacher interview 27)

Furthermore, projects in Cross-Square also shape the school-as-field by focusing on specific issues. The institutional pressures that push the school towards cooperation do not do so randomly. Projects often address a perceived deficiency in what families can provide for their children "in a neighborhood like this." Parents are often part of the target group. As I showed above, the school's partnerships cover topics such as child protection, nutrition, conflict resolution, support and counseling for children and families, homework tutoring, and after-school activities. In addition to such projects, the school also has a social worker who is responsible for helping out if conflicts arise with families, and the school cooperates closely with the child welfare agency. In total, the children's social context provides the focus for most 
additional projects and support structures for these topics are implemented inside the organization. Although this focus does match some of the school's, parents', and children's needs, the emphasis on the children's social context creates a specific kind of expertise, focus of attention, and taken-for-granted assumptions in CrossSquare (that differ in Roseville) and thus specifically localize the field by shaping the teachers' practices. The importance of these localizing processes becomes especially apparent when compared to the situation in Roseville.

\section{Roseville: Different workload, different institutional pressures, and the role of parents}

Teachers in Roseville also face institutional changes, such as funding cuts, but these have less of an impact than in Cross-Square. Experienced teachers tell stories of how they used to have "more time," "less pressure," and how things used to be "more relaxed" (Teacher interview 16). However, teachers also point out that, in comparison to contexts like Cross-Square, these changes are less problematic in Roseville.

Yet funding cuts are not the only thing to hit Cross-Square harder. Institutional pressures to open the school up to external partners are also less visible in Roseville. Due to their social composition, schools in privileged neighborhoods often face less pressure to appear legitimate. It is easier for them to produce good results and to be seen as organizations that satisfactorily fulfil their duties. Even if problems do exist, they are less often addressed through projects. To use the issue of parental participation: Although Roseville teachers often talk about the challenges of working with highly educated parents, there are usually no projects in place to help them negotiate their relationships with middle- or upper-class parents - as this group is traditionally not defined as "problematic" (for a similar argument, see Gomolla, 2009, p. 31).

Similar tendencies are reflected in the school's partnerships with the child welfare agency, secondary schools, and kindergartens. Here, too, the local authorities exert less pressure to cooperate with other organizations, as they often see social problems in Roseville families as off-limits. Although the school also has both a kindergarten commissioner, in charge of representing the school to local kindergartens, and a child-welfare contact person, these posts are considerably less visible in daily routines than in Cross-Square. G. Heinz, a teacher, explains: "I'm the contact person for the child welfare agency [...] you know, it's a job that I took on at some point, but I never really acted in this role." (Teacher interview 17). Again, this highlights how the effect of similar institutional pressures can play out differently depending on the local context in which it is implemented. Moreover, certain types of organizations - such as the neighborhood council—simply do not exist in privileged neighborhoods, and thus also do not push for partnerships. Similarly, charities that work with deprived families do not usually look for their target group in Roseville.

Moreover, not only the scope of projects diverges from that in Cross-Square, but also the kind of partnerships. If the Roseville school is involved in projects, teachers 
rarely have to apply for funding or to administer the eventual grant. School partnerships often come in the form of sponsorship: "We've just won over this bank [...] [to sponsor our school's homework diary for the children], a supermarket is donating limes for the summer party, yes [...] and yesterday, another bank sponsored the prize for the football competition." (Teacher interview 23). In addition, if external partners offer activities for the children, these are usually programs paid for by the parents, and the school thus has less responsibility for its coordination.

When asked whether partnerships and projects form a large part of their duties, Principal Deuft and Vice-Principal Scherk explain: "No, we meet with all of them once a year and then it works just fine!" (Teacher interview 23). In general then, Roseville primary school's professionals experience partnerships and projects as less time-consuming and less linked to additional work than do those of Cross-Square.

These differences, however, are not only a consequence of the different institutional pressures under which the Roseville school operates. Even when faced with similar institutional demands, the Roseville school can provide different organizational "answers" than the Cross-Square school. Its location in Roseville comes with a parental clientele that can provide resources in an uncomplicated fashion, thereby accelerating processes of informal privatization. Parents bring their economic, social, and cultural capital (Bourdieu, 1986) to the school and thus provide alternatives that allow the institution to forgo other forms of cooperation. As Peter, a physician, explains:

They had two professional dancers and they did this in the third and in the second grade $[\ldots]$ and, well, I guess this would not be possible in Cross-Square or similar neighborhoods because it would be unclear how to finance it, and here, we paid for it, the parents paid. (Parent interview 19)

This also releases teachers from the bureaucracy that comes with programs such as the earlier-mentioned "Bildungs- und Teilhabepaket" ("Education and Participation Package"). Instead, teachers can rely on parents' economic capital to cover similar costs. Moreover, the Roseville school receives the support of its friends' association. ${ }^{3}$ The principal, P. Deuft, explains:

$80 \%$ of the parents are members [...] that's a lot, and they give money and donate; alumni also donate sometimes and, well, ideas don't fail because of a lack of money here, instead, it's sometimes challenging to actually spend all the money. (Teacher interview 23)

This form of fundraising is much simpler, avoids time-intensive applications, and can be used more flexibly-which is quite different from projects that are financed by the neighborhood council in Cross-Square. Although the Cross-Square school also has a friends' association, membership numbers are lower and fees start at $€ 1$ per month-incoming donations are "very low," as Helena, one of the few middle-class mothers in Cross-Square, explains (Parent interview 10). The

\footnotetext{
${ }^{3}$ Charities generally made up of parents and sometimes teachers, with aims such as: raising additional funds for their child's school, providing facilities and equipment, improving the lives and experiences of children attending the school, and fostering good relationships between parents and staff.
} 
additional funds that the friends' association is able to bring in are mostly public funding, thus repeating the logic of publicly funded projects seen earlier.

In Roseville, parents also invest more than their economic capital (Bourdieu, 1986): They contribute their cultural capital, skills, and competencies by offering after-school activities such as a football club or by supporting class instruction. Moreover, parents often assist in the school's daily functioning, as the following anecdote reveals:

It's the afternoon and I enter the principal's office [...] A man in his 30s sits in front of her computer. [...] P. Deuft explains that this is a father [...] who works for an IT company. He created mailing lists for each class and maintains the school's website in his free time. (Author's field notes, Roseville primary school, January 16, 2013)

It is exactly this kind of additional support that the school in Cross-Square needs to organize externally through partnerships. The principal of Cross-Square's primary school, for example, had to find someone to reorganize the school's computer lab through an outside project. As she explains: "It's complicated and time consuming, and it requires energy and patience" (Author's field notes, Cross-Square primary school, June 19, 2012). In Roseville, the school can often access this kind of support much more directly through parents. Here, parents also use their social capital to support the school. When the school had trouble with their cleaning company, these problems "disappeared." C. Scherk, the vice-principal, explains that a mother had asked her husband, a lawyer, to look at the contract: "He checked what they actually had to clean" (Author's field notes, Roseville primary school, January 30, 2013).

Finally, Roseville's school-as-field is also shaped by the content of the school's partnerships and the kind of projects that are seen as adequate for a school in a privileged neighborhood. Here, the focus is not on child-protection issues, social problems, and additional support for families as in Cross-Square. Rather, children's individual talents and individualistic conditions are at the forefront. Projects often focus on giving students the opportunity to further develop their interests, rather than on providing them with any enrichment at all. Moreover, the presentation of children's achievements plays an important role. For example, the theatre, football, and basketball clubs regularly participate in Berlin-wide competitions. Beyond the question of developing talents, issues of concern focus on highly gifted, or highly sensitive children, attention deficit hyperactivity disorder (ADHD), or dyslexia and dyscalculia. When P. Deuft, the principal, talks about expanding partnerships, she focuses on giftedness rather than on intensifying partnerships with the child welfare agency: "In the area of giftedness, we could cooperate much more [...] I just went to a meeting on this with the local government $[\ldots]$ and we don't focus enough on highly gifted children and they need support as well!" (Author's field notes, Roseville primary school, March 14, 2013).

Roseville also has a teacher who explicitly focuses on supporting children with dyslexia - rather than employing a social worker, who supports families, as in Cross-Square. Berlin's school law (Grundschulverordnung (GsVO), 2005, §16) dictates that all schools must have teachers dedicated to helping dyslexic students; in 
practice, this never came up in Cross-Square, highlighting how similar institutional pressures are "activated" differently depending on the local context. It is in these areas that competences and additional knowledge are developed in the Roseville school. This has important consequences as it localizes the school-as-field by fostering a specific focus of attention, taken-for-granted assumptions, and interpretations that differ from the understandings in Cross-Square and thus can add to local inequalities.

\section{The Role of Local Settings for Educational Inequality}

In summary, then, neighborhoods localize schools-as-fields by introducing first, as social units, different social compositions, and with it different objective power positions within schools as well as different institutional conflicts over their legitimacy as organizations; second, as symbolic units, by infusing different symbolic meanings and hierarchies that entail various forms of symbolic violence or valorization; and finally, third, as administrative units, by structuring the institutional pressures of projects and partnerships that penetrate school-as-fields. Although I have separated these different factors for analytical purposes, they obviously can overlap, interact with, and reinforce each other. Together, they produce diverging fieldconstellations in different neighborhood contexts as institutional pressures and the objective power relations within and between organizations interact.

Teachers and other educational professionals are thus confronted with very differently localized schools-as-fields. Why is this important? Following Bourdieu, one can argue that different field constellations will also result in diverging daily understandings and taken-for-granted assumptions as well as practices of the actors involved in the field (e.g., Bourdieu, 1997/2000, p. 11). Localized schools-as-fields might thus result in diverging organizational practices in different neighborhoods. As I have shown in other writing (Nast, 2020), this becomes apparent in how Roseville and Cross-Square teachers more or less easily accept that their students will experience problems in school and address them with diverging levels of urgency; in the quality of teaching, the degree to which standards are fulfilled and the ways, in which teachers treat children; and in how school problems are framed and which kinds of solutions teachers see as adequate, ranging from contacting the child welfare agency, to calling the police, or sending children to therapy. These diverging organizational practices can differently affect children's chances of getting through school successfully — and can thus add to the already unequal conditions for children growing up in different neighborhood contexts.

To understand educational inequality, it is thus important to take local settings into account. This goes beyond the role of neighborhoods in sorting students into schools and shaping social compositions. As I have shown, if one understands schools as localized fields it becomes apparent how local contexts shape organizational practices in more complex ways. This insight not only helps one to better understand the complex processes that bring about educational inequality 
theoretically, but also to highlight how institutional changes in today's cities might play out differently in different contexts and thus might add to new patterns of neighborhood inequality in the field of education and beyond.

\section{References}

AlSayyad, N. (2004). Urban informality as a 'new' way of life. In A. Roy \& N. AlSayyad (Eds.), Urban informality: Transnational perspectives from the Middle East, South Asia and Latin America (pp. 7-30). Lanham: Lexington.

Amin, A., \& Thrift, N. (1996). Living in the global. In A. Amin \& N. Thrift (Eds.), Globalization, institutions, and regional development in Europe (pp. 1-22). Oxford, UK: Oxford University Press.

Arum, R. (2000). Schools and communities: Ecological and institutional dimensions. Annual Review of Sociology, 26, 395-418. https://doi.org/10.1146/annurev.soc.26.1.395

Ball, S. J., \& Vincent, C. (1998). 'I heard it on the grapevine': 'Hot' knowledge and school choice. British Journal of Sociology of Education, 19, 377-400. https://doi. org/10.1080/0142569980190307

Baumheier, U., \& Warsewa, G. (2009). Vernetzte Bildungslandschaften: Internationale Erfahrungen und Stand der deutschen Entwicklung [Networked educational landscapes: International experiences and status of the German development]. In P. Bleckmann \& A. Durdel (Eds.), Lokale Bildungslandschaften: Perspektiven für Ganztagsschulen und Kommunen (pp. 19-36). Wiesbaden: VS Verlag für Sozialwissenschaften. https://doi.org/10.1007/978-3-531-91857-0_2

Blokland, T. (2009). Celebrating local histories and defining neighbourhood communities: Place-making in a gentrified neighbourhood. Urban Studies, 46, 1593-1610. https://doi. org/10.1177/0042098009105499

Bourdieu, P. (1977). Outline of a theory of practice (R. Nice, Trans.). Cambridge, UK: Cambridge University Press. (Original work published 1972) https://doi.org/10.1017/CBO9780511812507

Bourdieu, P. (1986). The forms of capital. In J. G. Richardson (Ed.), Handbook of theory and research for the sociology of education (pp. 241-258). New York: Greenwood.

Bourdieu, P. (1987). The force of law: Toward a sociology of the juridical field. The Hastings Law Journal, 38, 805-853.

Bourdieu, P. (1990). The logic of practice (R. Nice, Trans.). Stanford, CA: Stanford University Press. (Original work published 1980)

Bourdieu, P. (2000). Pascalian meditations (R. Nice, Trans.). Stanford, CA: Stanford University Press. (Original work published 1997)

Bourdieu, P., \& Passeron, J.-C. (1990). Reproduction in education, society and culture (R. Nice, Trans.) (2nd ed.). London: Sage. (Original work published 1970)

Bourdieu, P., \& Wacquant, L. (1996). Reflexive Anthropologie (H. Beister, Trans.) [Reflexive Anthropology]. Frankfurt: Suhrkamp.

Butler, J. (2001). Psyche der Macht: Das Subjekt der Unterwerfung (R. Ansén, Trans.) [The Psychic Life of Power: Theories in Subjection]. Frankfurt: Suhrkamp. (Original work published 1997)

Butler, T., \& Hamnett, C. (2011a). Ethnicity, class and aspiration: Understanding London's new East End. Bristol, UK: Policy Press.

Butler, T., \& Hamnett, C. (2011b). 'Geography matters': The role distance plays in reproducing educational inequality in East London. Transactions of the Institute of British Geographers, 36, 479-500. https://doi.org/10.1111/j.1475-5661.2011.00444.x

Cheshire, P., \& Sheppard, S. C. (2004). Capitalising the value of free schools: The impact of supply characteristics and uncertainty. The Economic Journal, 114, F397-F424. https://doi. org/10.1111/j.1468-0297.2004.00252.x 
Coleman, J. S., Campbell, E. Q., Hobson, C. J., McPartland, J., Mood, A. M., Weinfeld, F. D., \& York, R. L. (1966). Equality of educational opportunity. Washington, D.C.: U.S. Government Printing Office.

Crozier, G. (2000). Parents and schools: Partners or protagonists? Stoke-on-Trent: Trentham.

DiMaggio, P. J., \& Powell, W. W. (1983). The iron cage revisited: Institutional isomorphism and collective rationality in organizational fields. American Sociological Review, 48, 147-160. https://doi.org/10.2307/2095101

DiMaggio, P. J., \& Powell, W. W. (1991). Introduction. In W. W. Powell \& P. J. DiMaggio (Eds.), The new institutionalism in organizational analysis (pp. 1-38). Chicago, IL: University of Chicago Press.

Duveneck, A. (2016). Bildungslandschaften verstehen: Zum Einfluss von Wettbewerbsbedingungen auf die Praxis [Understanding educational landscapes: The influence of competitive conditions on the practice]. Weinheim: Beltz Juventa.

Emirbayer, M., \& Johnson, V. (2008). Bourdieu and organizational analysis. Theory and Society, 37, 1-44. https://doi.org/10.1007/s11186-007-9052-y

Evans, W. N., Oates, W. E., \& Schwab, R. M. (1992). Measuring peer group effects: A study of teenage behavior. Journal of Political Economy, 100, 966-991. https://doi.org/10.1086/261848

Everett, J. (2002). Organizational research and the praxeology of Pierre Bourdieu. Organizational Research Methods, 5, 56-80. https://doi.org/10.1177/1094428102005001005

Fincke, G., \& Lange, S. (2012). Segregation an Grundschulen: Der Einfluss der elterlichen Schulwahl [Segregation at primary schools: The influence of the parental choice of school]. Retrieved from https://www.svr-migration.de/wp-content/uploads/2014/11/Segregation_an_ Grundschulen_SVR-FB_WEB.pdf

Freytag, T., \& Jahnke, H. (2015). Schulen und sozialräumliche Fragmentierung in städtischen Quartieren [Schools and sociospatial fragmentation in urban quarters]. Berichte. Geographie und Landeskunde, 89, 109-120.

Freytag, T., Jahnke, H., \& Kramer, C. (2015). Bildungsgeographie [Educational Geography]. Darmstadt: WBG.

Frumkin, P., \& Galaskiewicz, J. (2004). Institutional isomorphism and public sector organizations. Journal of Public Administration Research and Theory, 14, 283-307. https://doi.org/10.1093/ jopart/muh028

Gamsu, S. (2016). Moving up and moving out: The re-location of elite and middle-class schools from central London to the suburbs. Urban Studie, 53, 2921-2938. https://doi. org/10.1177/0042098015601593

Geipel, R. (1965). Sozialräumliche Strukturen des Bildungswesens: Studien zur Bildungsökonomie und zur Frage der gymnasialen Standorte in Hessen [Sociospatial structures of the education system: Studies on the economics of education and the question of the grammar school locations in Hesse]. Frankfurt: Diesterweg.

Gibbons, S., \& Machin, S. (2006). Paying for primary schools: Admission constraints, school popularity or congestion? The Economic Journal, 116, C77-C92. https://doi. org/10.1111/j.1468-0297.2006.01077.x

Gomolla, M. (2009). Elternbeteiligung in der Schule [Parental contribution at school]. In S. Fürstenau \& M. Gomolla (Eds.), Migration und schulischer Wandel: Elternbeteiligung (pp. 21-49). Wiesbaden: VS Verlag für Sozialwissenschaften. https://doi.org/10.1007/978-3-531-91487-9_2 Grundschulverordnung (GsVO) [Primary school regulation]. (2005, January 19). Berlin, Germany.

Harvey, D. (2005). Spaces of neoliberalization: Towards a theory of uneven geographical development. Hettner-Lectures: Vol. 8. Stuttgart: Franz Steiner.

Häussermann, H., Werwatz, A., Glock, B., Dohnke, J., \& Hausmann, P. (2011). Monitoring Soziale Stadtentwicklung 2011: Fortschreibung für den Zeitraum 2009-2010 [Monitoring social city development 2011: Update for the period 2009-2010]. Berlin: Senatsverwaltung für Stadtentwicklung und Umwelt Berlin.

Jencks, C., \& Mayer, S. E. (1990). The social consequences of growing up in a poor neighborhood. In L. E. Lynn \& M. G. H. McGeary (Eds.), Inner-city poverty in the United States (pp. 111-186). Washington, D.C.: National Academy. 
Johnston, R., Burgess, S., Wilson, D., \& Harris, R. (2006). School and residential ethnic segregation: An analysis of variations across England's local education authorities. Regional Studies, 40, 973-990. https://doi.org/10.1080/00343400601047390

Kahlenberg, R. D. (2003). All together now: Creating middle-class schools through public school choice. Washington, D.C.: Brookings Institution.

Lareau, A. (1987). Social class differences in family-school relationships: The importance of cultural capital. Sociology of Education, 60, 73-85. https://doi.org/10.2307/2112583

Logan, J. R., \& Molotch, H. L. (1987). Urban fortunes: The political economy of place. Berkeley, CA: University of California Press.

Lupton, R. (2004). Schools in disadvantaged areas: Recognising context and raising quality. CASEpaper, 76, 1-39.

Lupton, R. (2005). Social justice and school improvement: Improving the quality of schooling in the poorest neighbourhoods. British Educational Research Journal, 31, 589-604. https://doi. org/10.1080/01411920500240759

Massey, D. (1994). Space, place, and gender. Minneapolis, MN: University of Minnesota Press.

McDonough, P. M. (1997). Choosing colleges: How social class and schools structure opportunity. Albany, NY: State University of New York Press.

McNamara Horvat, E., Weininger, E. B., \& Lareau, A. (2003). From social ties to social capital: Class differences in the relations between schools and parent networks. American Educational Research Journal, 40, 319-351. https://doi.org/10.3102/00028312040002319

McNay, L. (2004). Agency and experience: Gender as a lived relation. In L. Adkins \& B. Skeggs (Eds.), Feminism after Bourdieu (pp. 175-190). Oxford: Blackwell.

Meusburger, P. (1998). Bildungsgeographie: Wissen und Ausbildung in der räumlichen Dimension [Educational geography: Knowledge and education in the spatial dimension]. Heidelberg: Spektrum.

Meyer, J. W., \& Rowan, B. (1977). Institutionalized organizations: Formal structure as myth and ceremony. American Journal of Sociology, 83, 340-363. https://doi.org/10.1086/226550

Müller, H.-P. (2002). Die Einbettung des Handelns: Pierre Bourdieus Praxeologie [The embedding of action: Pierre Bourdieus praxeology]. Berliner Journal für Soziologie, 12, 157-171. https:// doi.org/10.1007/BF03204050

Naidoo, R. (2004). Fields and institutional strategy: Bourdieu on the relationship between higher education, inequality and society. British Journal of Sociology of Education, 25, 457-471. https://doi.org/10.1080/0142569042000236952

Nast, J. (2020). Unequal neighbourhoods, unequal schools: Organisational habitus in deprived and privileged local contexts. Wiesbaden: Springer VS. https://doi.org/10.1007/978-3-658-27591-4

Noreisch, K. (2007). Choice as rule, exception and coincidence: Parents' understandings of catchment areas in Berlin. Urban Studies, 44, 1307-1328. https://doi.org/ $10.1080 / 00420980701302320$

Opdenakker, M.-C., van Damme, J., de Fraine, B., van Landeghem, G., \& Onghena, P. (2002). The effect of schools and classes on mathematics achievement. School Effectiveness and School Improvement, 13, 399-427. https://doi.org/10.1076/sesi.13.4.399.10283

Paulle, B. (2013). Toxic schools: High-poverty education in New York and Amsterdam. Chicago, IL: University of Chicago Press. https://doi.org/10.7208/chicago/9780226066554.001.0001

Roy, A. (2011). Slumdog cities: Rethinking subaltern urbanism. International Journal of Urban and Regional Research, 35, 223-238. https://doi.org/10.1111/j.1468-2427.2011.01051.x

Skeggs, B. (1997). Formation of class and gender: Becoming respectable. London: Sage.

Skeggs, B. (2004). Exchange, value and affect: Bourdieu and 'the self'. In L. Adkins \& B. Skeggs (Eds.), Feminism after Bourdieu (pp. 75-95). Oxford: Blackwell.

Sykes, B., \& Musterd, S. (2011). Examining neighbourhood and school effects simultaneously: What does the Dutch evidence show? Urban Studies, 48, 1307-1331. https://doi. org/10.1177/0042098010371393

Thrupp, M. (1999). Schools making a difference: Let's be realistic! School mix, school effectiveness and the social limits of reform. Buckingham, UK: Open University Press. 
Thrupp, M., Lauder, H., \& Robinson, T. (2002). School composition and peer effects. International Journal of Educational Research, 37, 483-504. https://doi.org/10.1016/ S0883-0355(03)00016-8

Valverde, M. (1994). Moral capital. Canadian Journal of Law \& Society, 9, 213-232. https://doi. org/10.1017/S0829320100003574

van Ewijk, R., \& Sleegers, P. (2009). The effect of peer socioeconomic status on student achievement: A meta-analysis. Educational Research Review, 5, 134-150. https://doi.org/10.2139/ ssrn. 1402645

van Zanten, A. (2005). New modes of reproducing social inequality in education: The changing role of parents, teachers, schools and educational policies. European Educational Research Journal, 4, 155-169. https://doi.org/10.2304/eerj.2005.4.3.1

Vertovec, S. (2007). Super-diversity and its implications. Ethnic and Racial Studies, 30, 1024-1054. https://doi.org/10.1080/01419870701599465

Villa, P.-I. (2011). Symbolische Gewalt und ihr potenzielles Scheitern: Eine Annäherung zwischen Butler und Bourdieu [Symbolic violence and its potential failure: An approximation between Butler and Bourdieu]. Österreichische Zeitschrift für Soziologie, 36, 51-69. https://doi. org/10.1007/s11614-011-0003-5

Vincent, C. (1996). Parents and teachers: Power and participation. London: Routledge. https:// doi.org/10.4324/9781315043173

Wacquant, L. (2008). Urban outcasts: A comparative sociology of advanced marginality. Cambridge: Polity.

Warrington, M. (2005). Mirage in the desert? Access to educational opportunities in an area of social exclusion. Antipode, 37, 796-816. https://doi.org/10.1111/j.0066-4812.2005.00526.x

Open Access This chapter is licensed under the terms of the Creative Commons Attribution 4.0 International License (http://creativecommons.org/licenses/by/4.0/), which permits use, sharing, adaptation, distribution and reproduction in any medium or format, as long as you give appropriate credit to the original author(s) and the source, provide a link to the Creative Commons license and indicate if changes were made.

The images or other third party material in this chapter are included in the chapter's Creative Commons license, unless indicated otherwise in a credit line to the material. If material is not included in the chapter's Creative Commons license and your intended use is not permitted by statutory regulation or exceeds the permitted use, you will need to obtain permission directly from the copyright holder. 